\title{
MANAJEMEN BIAYA SEKOLAH \\ DALAM MENINGKATKAN MUTU PENDIDIKAN
}

\author{
Himyar Pasrizal \\ Dosen Prodi MPI PPs STAIN Batusangkar \\ e-mail: himyarpasriza @yahoo.co.id
}

$+2$

\begin{abstract}
Schooled cost management effectively and efficient constitute activity something that essential in order to education upgrade. The aims of state to smarten up nation life will be reached along with be reached intent schooled and student individual which is get education and up to achievement which at the farthest. In order to intent attainment with that with upgrade education therefore has to be backed up by finance that is equal to of all party as one be worded in UU RI No.20 Year 2003, about National Education System, which is education Finance becomes to carry the ball with among Government, Local government, and society. Beside it also schooled finances source shall determine to base justice principle, sufficiency, and sustainability.
\end{abstract}

Key words: Manajemen biaya, mutu pendidikan

\section{PENDAHULUAN}

Keberhasilan pendidikan di sebuah negara sangat tergantung kepada sumber daya pendidikan yang dimiliki oleh negara tersebut. UU RI No.20 Tahun 2003, tentang Sistem Pendidikan Nasional, menjelaskan bahwa sumber daya pendidikan adalah segala sesuatu yang dipergunakan dalam penyelenggaraan pendidikan yang meliputi tenaga kependidikan, masyarakat, dana, sarana, dan prasarana. Dapat dipahami dengan jelas bahwa dana merupakan salah satu sumber daya pendidikan, maka untuk itu perlu dilakukan pengelolaan pendanaan pendidikan yang kemudian kita sebut sebagai manajemen biaya sekolah. Sumber pendanaan pun harus ditentukan berdasarkan prinsip keadilan, kecukupan, dan keberlanjutan. Berdasarkan Undang-Undang di atas, maka sumber pembiayaan sekolah dapat dibagi menjadi dua ketegori utama, yaitu sumber pembiayaan sekolah yang berasal dari pemerintah dan masyarakat.

Adapun sumber dari pemerintah dikelompokkan lagi menjadi dua, yaitu pemerintah pusat dan pemerintah daerah. Sedangkan sumber dana dari masyarakat dapat dikelompokkan sebagai masyarakat umum dan orang tua siswa. Dengan adanya berbagai pihak sebagai sumber pembiayaan sekolah, maka perlu diperjelas atau dipertegas tugas dan tanggung jawab masing-masingnya. Di pihak pemerintah perlu membuat anggaran untuk pendidikan di sekolah yang proporsional dengan APBN/APBD, misalnya anggaran 
untuk pendidikan harus dialokasikan sebesar 20\%. Seperti yang diatur dalam UU Sisdiknas pasar 46, ayat 2:Pemerintah dan Pemerintah Daerah bertanggung jawab menyediakan anggaran pendidikan sebagaimana diatur dalam Pasal 31 ayat (4) Undang-Undang Dasar Negara Republik Indonesia Tahun 1945. Pembiayaan yang berasal dari mayarakat yaitu biaya sekolah yang harus ditanggung oleh orang tua siswa sesuai dengan hasil musyawarah dalam komite sekolah dan ditambah dana dari masyarakat umum yang bersifat sebagai sumbangan.

\section{PEMBANGUNAN PENDIDIKAN NASIONAL}

UU Sisdiknas Tahun 2003 pasal 1 poin 2, menjelaskan bahwaPendidikan nasional adalah pendidikan yang berdasarkan Pancasila dan Undang-Undang Dasar Negara Republik Indonesia Tahun 1945 yang berakar pada nilainilai agama, kebudayaan nasional Indonesia dan tanggap terhadap tuntutan perubahan zaman. Pembangunan pendidikan nasional harus dilakukan secara merata di seluruh Indonesia. Tetapi kendala teknis masih banyak terjadi seperti aturan birokrasi yang panjang, pengambilan keputusan dalam pendanaan yang masih lambat. Nandika (2005, dalam Irianto, 2011:11) mengemukakan bahwa terdapat banyak masalah dan tantangan yang dihadapi dalam pembangunan pendidikan di Indonesia, yaitu:

1. Tingkat pendidikan masyarakat relatif rendah.

2. Dinamika perubahan struktur penduduk belum sepenuhnya terakomodasi dalam pembangunan pendidikan.

3. Kesenjangan tingkat pendidikan.
4. Good governance yang belum berjalan secara optimal.

5. Fasilitas pelayanan pendidikan yang belum memadai dan merata.

6. Kualitas pendidikan relatif rendah dan belum mampu memenuhi kompetensi peserta didik.

7. Pendidikan tinggi masih menghadapi kendala dalam mengembangkan dan menciptakan IPTEK.

8. Manajemen pendidikan belum berjalan secara efektif dan efisien.

9. Anggaran pembangunan pendidikan belum tersedia secara memadai.

Dari sembilan poin yang dikemukakan Nandika, poin terakhir artinya anggaran dana yang dialokasikan untuk pendidikan sebesar 20\% belum mampu direalisasikan karena terjadi pemotongan atau penyimpangan dan penyalahgunaan anggaran. Walaupun pada akhirnya dapat terealisasi pada tahun 2008, namun dalam pelaksanaannya terkesan tidak siap sehingga menimbulkan berbagai macam polemik.

Pembangunan pendidikan nasional tidak hanya didukung oleh biaya namun juga harus didukung oleh mutu dan relevansi layanan pendidikan. Berdasarkan visi 2025 pembangunan pendidikan nasional "Insan Indonesia Cerdas dan Kompetitif”, maka pada periode 2010-2014 menyandang tema "Penguatan Pelayanan", sehingga Pendidikan Nasional mempunyai visi 2014 "Terselenggaranya Layanan Prima Pendidikan Nasional untuk Membentuk Insan Indonesia Cerdas Komprehensif". Untuk dapat merealisasikan visi 2014 tersebut maka 
Kementerian Pendidikan dan Kebudayaan Republik Indonesia menetapkan lima misi pokok, yaitu:

1. Meningkatkan Ketersediaan Layanan Pendidikan

2. Meningkatkan Keterjangkauan Layanan Pendidikan

3. Meningkatkan Kualitas/Mutu dan Relevansi Layanan Pendidikan

4. Meningkatkan Kesetaraan Memperoleh Layanan Pendidikan

5. Meningkatkan Kepastian/Keterjaminan Memperoleh Layanan Pendidikan

Misi ketiga yang diemban dalam pembangunan pendidikan nasional yaitu dalam meningkatkan kualitas dan relevansi layanan pendidikan memberikan gambaran bahwa pendidik dan tenaga kependidikan memegang peranan penting. Pendidikan yang berkualitas akan dapat diberikan oleh pendidik dan tenaga kependidikan yang mempunyai kemampuan yang baik dan memenuhi standar proses dalam pendidikan.

\section{KONSEP BIAYA PENDIDIKAN}

Pembiayaan pendidikan merupakan kegiatan mendistribusikan manfaat, hak, dan kewajiban pendidikan kepada masyarakat. Pembiayaan pendidikan sangat didukung oleh pendapatan dari sektor pajak. Artinya semakin tinggi penerimaan pajak maka APBN juga semakin besar dan anggaran untuk pendidikan menjadi bertambah. Konsep penting dalam pendanaan dan pembiayaan adalah seberapa besar uang yang diperoleh, dari jumlah tersebut berapa jumlah yang akan dibelanjakan dan kepada siapa uang itu dibelanjakan. Maka itu pemerintah menyelesaikannya dengan membuat rencana anggaran pendapatan dan belanja negara/daerah.

Lebih jauh dapat dipahami bahwa pembiayaan pendidikan merupakan sejumlah penerimaan uang yang kemudian dibelanjakan untuk berbagai keperluan kegiatan pendidikan, seperti pembayaran gaji guru, pengadaan dan perbaikan bangunan, pengadaan pelengkapan dan mobiler, pengadaan alat tulis kantor, kegiatan pengelolaan pendidikan, kegiatan supervisi pendidikan, dan kegiatan ekstra kurikuler. Definisi lain mengemukakan (Nanang Fattah, 2002:112), bahwa pembiayaan pendidikan merupakan jumlah uang yang dihasilkan dan dibelanjakan untuk berbagai keperluan penyelenggaraan pendidikan yang mencakup gaji guru, peningkatan profesional guru, sarana ruang belajar, pengadaan perlengkapan/mobiler, alat-alat dan buku pelajaran, alat tulis kantor, kegiatan ekstra kurikuler, kegiatan pengelolaan pendidikan, dan supervisi pendidikan. Untuk lebih memahami tentang konsep pembiayaan dan pendidikan perlu dicermati pokok-pokok terminologi berikut: (lin Sunarti, 2007:11-14).

\section{a. Objek Biaya}

Suatu program selalu terkait dengan berbagai aktifitas sebagai ujung tombak (operating core) sistem lembaga atau organisasi yang membutuhkan biaya. Objek biaya adalah merupakan biaya dari seluruh kegiatan yang ada. Sehingga dapat dikatakan objek biaya merupakan akumulasi biaya dari berbagai macam kegiatan. Dari penjelasan 
tersebut maka dapat disimpulkan bahwa pembiayaan pendidikan adalah suatu analisis tentang sumber-sumber penerimaan (revenue), dan penggunaan biaya (expenditure) yang diperuntukkan untuk pengelolaan pendidikan secara efisien untuk mencapai tujuan.

Pendidikan sebagai suatu lembaga atau organisasi yang tidak berorientasi kepada laba maka objek biayanya adalah jasa dengan seluruh elemen (perangkat keras dan perangkat lunak atau hard ware and soft ware) yang melekat pada prosesnya. Oleh sebab itu sasaran akuntan manajemen pada kasus ini terutama terhadap pengelolaan biaya yang dikeluarkan untuk menyediakan jasa bagi masyarakat, lembaga, organisasi, departemen, proyek, dan atau memelihara catatan yang akurat dari biaya yang dikeluarkan.

\section{b. Informasi Manajemen Biaya}

Manajemen biaya adalah suatu aktifitas pengelolaan biaya dan dapat berfungsi sebagai alat perencanaan, keputusan, dan kontrol dengan demikian kegiatan dapat dilakukan secara maksimal, efektif, dan efisien dalam mencapai tujuan baik itu lembaga yang bersifat profit maupun non profit. Untuk mencapai keberhasilan dengan daya saing tinggi, lembaga pendidikan perlu memfokuskan perhatian pada informasi sumber biaya atau yang lain yang memiliki waktu lebih panjang dan berkelanjutan.

Suatu lembaga harus tahu berapa biaya yang dihabiskan untuk melakukan suatu jasa atau produk tertentu atau pengembangan suatu jasa baru. Informasi digunakan untuk mementukan harga untuk mengubah produk atau jasa dalam rangka meningkatkan profitabilitas dan untuk memperbarui fasilitas layanan pada saat yang tepat, dan untuk menentukan metode layanan. Pengelolaan dan operasional manajemen biaya dibutuhkan untuk memberikan dasar yang wajar dan efektif untuk mengidentifikasi operasi yang tidak efisien dan untuk memberikan penghargaan serta dukungan kepada para manajer yang paling efektif.

Informasi manajemen biaya dibutuhkan untuk memberikan catatan yang akurat tentang persediaan dan aset yang lainnya. Dalam konteks pembiayaan pendidikan, informasi biaya ini dapat dikaitkan dengan informasi sumber biaya, baik dari pemerintah, orang tua, masyarakat, dan potensi lain yang mungkin dimanipulasi menjadi sumber biaya untuk pendidikan. Kemudian memberi informasi tentang sistem layanan proses belajar mengajar yang dikaitkan dengan biaya yang layak untuk suatu layanan yang lebih baik serta upaya mendukung keputusan dengan program yang harus dilakukan dan pelaporan biaya secara baik dan benar sebagai wujud pertanggung jawaban manajemen.

\section{c. Pembiayaan (financing)}

Pembiayaan merupakan kegiatan yang dilakukan untuk mengalokasikan dana yang ada. Pembiayaan pendidikan merupakan dana-dana yang dikeluarkan dan diinvestasikan dalam proses pendidikan, sehingga pembiayaan merupakan fungsi dari pengumpulan dana dari berbagai sumber yang memungkinkan. Sedangkan biaya pendidikan adalah merupakan seluruh usaha yang dilakukan oleh pemerintah dan masyarakat 
pendidikan baik berupa uang maupun non moneter.

Pembiayaan pendidikan harus dilakukan secara adil, merata, berkecukupan, dan berkesinambungan. Hal ini bertujuan untuk mencegah terjadinya ketimpangan dan ketidaksinkronan antar lembaga pendidikan yang berujung pada inefisiensi pembiayaan. Sehingga dalam melakukan penganggaran dan pendistribusian dalam hal pembiayaan pendidikan, perlu dicermati beberapa hal berikut: (Irianto, 2011:88).

1. Bagaimana dana dan fasilitas pendidikan didistribusikan ke daerah-daerah dan jenis serta jenjang pendidikan yang berbeda?

2. Bagaimana dampak dari bantuan dan subsidi pemerintah dalam meningkatkan kesejahteraan masyarakat setempat?

3. Apakah investasi pendidikan dapat memeratakan pendapatan, sehingga jurang perbedaan antara yang kaya dan yang miskin semakin pendek?

4. Bagaimana efektifitas pendidikan sebagai alat pemerataan?

\section{d. Keuangan (finance)}

Bagian keuangan sebuah lembaga pendidikan merupakan aktifitas kunci yang harus mempunyai tata kelola yang baik. Salah dalam pengelolaan keuangan sebuah lembaga pendidikan bisa mengalami kekurangan dana, kekacauan, bahkan kebangkrutan. Aktifitas di bagian keuangan sebuah lembaga pendidikan tidak hanya mencakup uang pembayaran yang sah seperti gaji dan honor atau upah, tapi juga kegiatan-kegiatan yang berhubungan dengan perbankan. Keuangan (finance) dapat didefinisikan sebagai seni untuk mendapatkan alat pembayaran, dalam bidang keuangan yang meliputi pemeliharaan kas yang memadai dalam bentuk uang atau kredit disesuaikan dengan kebutuhan organisasi. Alat yang digunakan dalam keuangan meliputi seluruh metode peminjaman uang dan pertukaran satu jenis hak yang berkenaan dengan keuangan dengan yang lainnya.

\section{e. Anggaran (budget)}

Anggaran merupakan suatu instrumen yang dirancang untuk memfasilitasi perencanaan dan juga memberikan sebuah konteks proses perencanaan dalam pemilihan langkah-langkah dalam mencapai tujuan yang ditetapkan. Budget merupakan dokumen yang meringkaskan keputusan yang direncanakan, dan dapat dijadikan sebagai alat untuk memastikan penggunaan dana masyarakat secara jujur dan hati-hati. Prosedur penganggaran dilakukan dengan: (1) menyusun ramalan tentang kemungkinan pendapatan dan belanja selama periode tertentu, (2) menetapkan anggaran berdasarkan ramalan, (3) statistik pelaksanaan dikumpulkan dan dibandingkan dengan dugaan-dugaan, (4) mengukur varian-varian dan menganalisis penyebabnya, dan (5) melakukan perbaikan.

Beberapa faktor yang perlu di pertimbangkan dalam membuat anggaran adalah: (1) permintaan terhadap hasil produksi dan stabilitas permintaan potensi dasar, (2) jenis-jenis hasil produksi yang dibuat dan sifat hasil produksi yang dibuat, (3) kemampuan menyusun jadwal dan mengatur pelaksanaan, (4) jumlah dana yang dipergunakan 
dibandingkan dengan hasil yang mungkin dicapai, dan (5) perencanaan dan pengawasan.

\section{f. Biaya (cost)}

Biaya adalah pengorbanan baik berupa uang maupun non uang sebagai kompensasi atas sesuatu yang diterima. Biaya dialokasikan dan digunakan atau dibelanjakan untuk terlaksananya berbagai fungsi kegiatan dalam mencapai tujuan yang ditetapkan. Definisi lain mengemukakan bahwa biaya adalah harga pokok yang merupakan gambaran pengorbanan dalam pengertian kuantitatif pada saat barang atau jasa dipertukarkan. Di sisi lain dapat diartikan bahwa harga pokok merupakan nilai pengorbanan dalam pengertian uang yang diberikan kepada produksi yang melekat pada hasil produksi, karena itu harga pokok dapat pula diartikan sebagai pengorbanan biaya yang rasional, tidak dapat dihindarkan dan memberikan kegunaan terhadap produksi.

\section{g. Pemicu Biaya (cost driver)}

Perubahan pada biaya total dipengaruhi oleh pemicu biaya. Artinya pembicu biaya merupakan faktor yang memberikan dampak terhadap perubahan biaya total. Pemicu biaya (cost driver) memberikan efek terhadap perubahan level biaya total suatu objek biaya. Identifikasi dan analisis terhadap cost driver merupakan langkah penting dalam analisis strategik dan manajemen biaya pada suatu organisasi.

Proses pembiayaan aktifitas pendidikan sebagai suatu lembaga non profit yang bergerak di bidang jasa dipengaruhi oleh cost driver. Misalnya, faktor-faktor yang menjadi pemicu biaya diantaranya adalah jumlah jam mengajar guru, media pengajaran, dan buku teks yang digunakan dan fasilitas pendukung yang sifatnya temporer. Program-program pendidikan yang ditawarkan oleh sekolah yang dapat meningkatkan dan mengembangkan keterampilan lulusan dalam pendidikan dapat juga dijadikan sebagai pemicu biaya yang diakumulasi. Cost drivertermasuk pihak-pihak yang ikut memikirkan program-program yang akan dilaksanakan serta biaya yang diakibatkan/dipicu oleh program yang dibuat.

\section{BIAYA PENDIDIKAN/SEKOLAH}

Biaya sekolah seorang siswa dapat dikelompokkan menjadi dua sumber utama, yaitu sumber internal dan eksternal. Pada sumber internal, biaya sekolah berasal dari orang tua siswa (walaupun ada sedikit yang dapat berasal dari siswa itu sendiri karena dia ikut membantu orang tua dalam hal mencari nafkah). Seperti yang dijelaskan dalam ayat 8 pada surat Al Ankabut berikut:

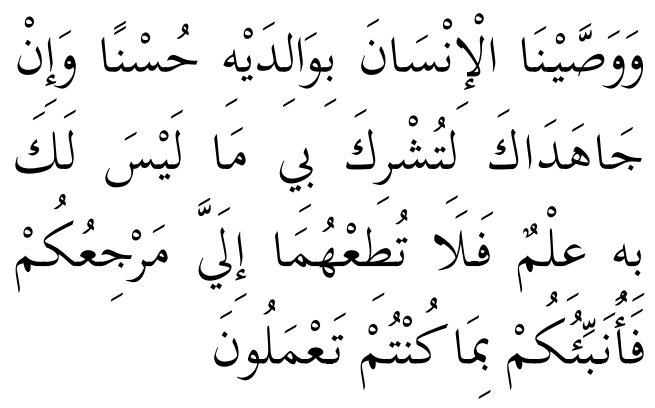

Artinya: Dan Kami wajibkan manusia (berbuat) kebaikan kepada dua orang ibubapaknya. dan jika keduanya memaksamu untuk mempersekutukan aku dengan sesuatu yang tidak ada pengetahuanmu tentang itu, Maka janganlah kamu mengikuti keduanya. hanya kepada-Ku-lah kembalimu, lalu aku kabarkan kepadamu apa yang telah kamu kerjakan. (QS 29:8). 
Sedangkan pada sumber eksternal biaya sekolah berasal dari pemerintah, perusahaan, dan masyarakat. Untuk mencapai keberhasilan mutu pendidikan maka kedua macam biaya tersebut harus bersinergi.

Menurut PP No 48 Tahun 2008 ada tiga jenis biaya pendidikan, yaitu:

1. Biaya Satuan Pendidikan, adalahbiaya penyelenggaraan pendidikan pada tingkat satuan pendidikan,

2. Biaya Penyelenggaraan dan/atau Pengelolaan Pendidikan, adalah biaya penyelenggaraan dan/atau pengelolaan pendidikan oleh Pemerintah, pemerintah provinsi, pemerintah kabupaten/kota, atau penyelenggara/satuan pendidikan yang didirikan masyarakat,

3. Biaya Pribadi Peserta Didik, adalahbiaya pendidikan yang harus dikeluarkan oleh peserta didik untuk bisa mengikuti proses pembelajaran secara teratur dan berkelanjutan.

Biaya satuan pendidikan terdiri dari biaya investasi adalah biaya penyediaan sarana dan prasarana, pengembangan sumber daya manusia, dan modal kerja tetap; biaya operasi, terdiri dari biaya personalia dan biaya nonpersonalia; bantuan biaya pendidikan yaitu dana pendidikan yang diberikan kepada peserta didik yang orang tua atau walinya tidak mampu membiayai pendidikannya; beasiswa adalah bantuan dana pendidikan yang diberikan kepada peserta didik yang berprestasi.

Biaya penyelenggaraan dan atau pengelolaan pendidikan, antara lain terdiri dari bantuan/ hibah pemerintah, di mana dana itu harus dikelola berdasarkan pada prinsip keadilan, efisiensi, transparansi, dan akuntabilitas publik. Misalnya dana Bantuan Operasional Sekolah (BOS) atau Biaya Operasional Pendidikan (BOP). Terdapat dua hal penting dalam konsep biaya di sekolah, yaitu biaya pendidikan secara keseluruhan (total cost) dan biaya satuan per siswa. Biaya satuan di tingkat sekolah merupakan jumlah keseluruhan biaya pendidikan tingkat sekolah dalam kurun waktu satu tahun pelajaran dan berasal dari orang tua, masyarakat, dan pemerintah.

Untuk memenuhi standar pelayanan minimal (SPM) di sekolah maka pemerintah menyalurkan dana BOS. Adapun tujuan dana BOS adalah untuk meringankan beban masyarakat terhadap pembiayaan pendidikan dalam rangka wajib belajar sembilan tahun yang bermutu. Penggunaan dana BOS (tahun 2012) berdasarkan keputusan pemerintah adalah sebagai berikut: (Kemendikbud, 2012:12).

1. Pembelian/penggandaan buku teks pelajaran,

2. Kegiatan dalam rangka penerimaan siswa baru,

3. Kegiatan pembelajaran dan ekstra kurikuler siswa,

4. Kegiatan Ulangan dan Ujian,

5. Pembelian bahan-bahan habis pakai,

6. Langganan daya dan jasa,

7. Perawatan sekolah,

8. Pembayaran honorarium bulanan guru honorer dan tenaga kependidikan honorer,

9. Pengembangan profesi guru,

10. Membantu siswa miskin, 
11. Pembiayaan pengelolaan BOS,

12. Pembelian perangkat komputer,

13. Biaya lainnya jika seluruh komponen 1 s.d 12 telah terpenuhi pendanaannya dari BOS.

Biaya pribadi peserta didik merupakan biaya sekolah yang berasal dari siswa (orang tua sendiri). Dukungan biaya pribadi sangat mempengaruhi kelancaran dan kesuksesan pendidikan siswa tersebut. Kemampuan masing-masing pribadi berbeda-beda, sehingga besaran biaya pribadi peserta didik juga bervariasi. Secara umum, siswa dalam level pendidikan wajib belajar sembilan tahun akan memerlukan biaya pribadi tersebut, seperti biaya pendaftaran, uang pangkal, biaya baju seragam, biaya kegiatan satu tahun, dan biaya buku untuk satu tahun.

\section{PENUTUP}

Pembiayaan atau pengelolaan dana sekolah memegang peranan penting dalam mencerdaskan kehidupan bangsa. Untuk itu perlu dilakukan dengan sebaik-baiknya dengan kegiatan yang efektif dan efisien serta tercapainya tujuan pendidikan nasional yaitu menjadikan masyarakat Indonesia yang cerdas dan kompetitif. UU RI No.20 Tahun 2003, tentang Sistem Pendidikan Nasional, mengemukakan bahwa sumber pendanaan harus ditentukan berdasarkan prinsip keadilan, kecukupan, dan keberlanjutan. Hal ini berarti dana-dana yang berasal dari pemerintah, masyarakat, dan orang tua siswa harus proporsional. Selanjutnya dalam pembiayaan pendidikan yaitu pengelolaan dana pendidikan didasarkan pada prinsipkeadilan, efisiensi, transparansi, dan akuntabilitas publik.
Peningkatan dan penjaminan mutu pendidikan dapat tercipta dengan dukungan pengelolaan biaya pendidikan yang baik. UndangUndang Sisdiknas pasal 50, menjelaskan bahwa Pemerintah menentukan kebijakan nasional dan standar nasional pendidikan untuk menjamin mutu pendidikan nasional. Peningkatan mutu pendidikan nasional harus didukung dengan kecukupan dana, sarana dan prasarana yang baik dan sumber dayamanusia yang handal, yaitu pendidik, tenaga kependidikan, dan masyarakat. Dengan sumber daya yang unggul dan pengelolaan biaya sekolah yang baik akan dapat menghasilkan mutu pendidikan yang berkualitas.

\section{KEPUSTAKAAN ACUAN}

Echols, John, M. dan Shadily Hasan,Kamus Inggris Indonesia, Jakarta: PT. Gramedia, 1996.

Fattah, Nanang,Ekonomi dan Pembiayaan Pendidikan,Bandung: PT. Rosda Karya, 2002.

Irianto, Agus, Pendidikan sebagai Investasi dalam Pembangunan Suatu Bangsa, Jakarta: Kencana, 2011.

Kemendikbud,Bahan Raker Komisi X DPR RI dengan Menteri Pendidikan dan Kebudayaan, Jakarta: Kemendikbud, 2012. , Kebijakan Pembangunan Pendidikan Dasar di Daerah Perbatasan, Jakarta: Kemendikbud, 2012.

Sunarti, Iin,Sistem Manajemen Pembiayaan Pendidikan, Equilibrium, Vol. 3 No. 6, 2007. 